\title{
FINANCIAL INCLUSION DAN FINANCIAL EXCLUSION DI PERBANKAN SYARIAH
}

\author{
Ahmad Rodoni, Novia Nengsih, Lili Supriyadi \\ Universitas Islam Negeri (UIN) Syarif Hidayatullah Jakarta
}

\begin{abstract}
This paper delvs a set of 'financial exclusion' factors in the Syari'ah (Islamic-law based) banking and measures its inclusive financial index. The financial exclusion is a condition, in which society has an obstacle to have an access into a financial institution. In contrast, the 'financial inclusion' is a process, in which a financial institution paves an access into a formal financial institution for unbankable people. This study is descriptive and qualitative. That is, the qualitative analysis uses the analytical technique data developed by Miles and Huberman (2009), such as data reduction, data display, and drawing or verivication of conclusion. Meanwhile, Quantitative analysis uses an Inclusive Financial Index (Indeks Keuangan Inklusif/IKI), such as dimensions attributed to the banking services, such as access, element of usage, and component of quality. This research employs primary resources resulted from interview and macro economic data, particularly sector of banking services. Additionally, this paper also refers to its secondary resources, such as financial report of Syari ah banking dated from 2014 to 2016, and findings of diverse resources in terms of data, journals, books, and others connected to this study.
\end{abstract}

Key words: financial inclusion, financial exclusion, syari ah banking.

\section{A. Pendahuluan}

Indonesia merupakan negara mayoritas muslim. Data BPS menyebutkan lebih kurang 85 persen warga negara Indonesia merupakan muslim. Bonus demografi ini berkontribusi positif kepada perkembangan perbankan syariah. Sejak berdiri tahun 1992 sampai 2016 perbankan syariah sudah memiliki 13 Bank Umum Syariah dengan 2138 jumlah kantor, 22 Unit Usaha Syariah dengan 693 kantor cabang, 1.399 kantor cabang pembantu dan, dan 427 kantor kas serta 162 Bank Pembiayaan Rakyat Syariah (BPRS) dengan 471 kantor cabang. (Statistik Perbankan Syariah OJK, 2016). 
Kehadiran perbankan syariah ini diharapkan mampu membantu menyelesaikan persosalan kemiskinan di Indonesia. Kemiskinan di Indonesia jika diukur dengan menggunakan standar Bank dunia yaitu mereka yang berpenghasilan kurang dari USD S2 per hari, maka sekitar 50,6 persen penduduk Indonesia merupakan masyarakat miskin (survei Bank Dunia 2015). Ini menunjukkan bahwa sebagian besar penduduk Indonesia hidup hampir di bawah garis kemiskinan.

Badan Pusat Statistik (BPS) mencatat penduduk Indonesia yang masih hidup di bawah garis kemiskinan per Maret 2016 mencapai 28,01 juta orang. Angka ini sekitar 10,86 persen dari jumlah penduduk nasional. Jumlah penduduk miskin tersebut turun 0,58 juta orang dibandingkan periode Maret tahun sebelumnya. BPS membagi data kemiskinan menjadi penduduk miskin perkotaan dan pedesaan. Jumlah penduduk miskin di daerah perkotaan turun 280 ribu orang pada Maret 2016 dibandingkan September 2015. Sedangkan untuk penduduk miskin daerah pedesaan mengalami penurunan sebesar 220 ribu orang ketimbang periode serupa tahun lalu. (Badan Pusat Statistik, 2016).

Meskipun kemiskinan Indonesia cenderung menurun pada 2016, namun World Bank menilai bahwa ketimpangan ekonomi Indonesia semakin melebar dalam 15 tahun terakhir. Terlihat dari koefisien gini Indonesia tahun 2016 mencapai 0,397 dari sebelumnya 0,30 tahun 2000. Ini merupakan pekerjaan bersama pemerintah dan masyarakat yang harus segera terselesaikan.

Kemiskinan, pengangguran, dan ketidakmerataan ekonomi sebenarnya dilatarbelakangi oleh kesulitan masyarakat dalam mendapatkan akses modal. Akses masyarakat Indonesia terhadap lembaga keuangan khususnya perbankan masih sangat rendah. Hasil penelitian World Bank menjelaskan bahwa financial inclusion index Indonesia hanya 19,6 persen. Ini masih jauh di bawah negara-negara lain seperti Malaysia 66, 7 persen, Philipina 26,5 persen, Thailand 77,7 persen, China 63,8 persen, dan negara lainnya. (World Bank, 2011).

Kemiskinan di Indonesia juga dilatarbelakangi oleh financial exclusion. Indonesia termasuk negara dengan tingkat financial exclusion cukup tinggi. Hal ini terlihat dari beberapa hasil survei dan penelitian yang dilakukan oleh beberapa lembaga nasional maupun internasional. Hasil survei lembaga Demografi FEUI tahun 2012, hanya $35,51 \%$ penduduk dewasa Indonesia yang mempunyai rekening di lembaga keuangan formal. Survei tersebut sejalan dengan hasil survei rumah tangga Bank Indonesia tahun 2011 yang menunjukan bahwa 
hanya $48 \%$ penduduk Indonesia yang memiliki tabungan di bank dan lembaga keuangan non bank serta non lembaga keuangan (non formal).

Keadilan, kemakmuran, dan kesejahteraan rakyat yang menjadi cita-cita bangsa sebagaimana tertuang pada pembukaan UndangUndang Dasar 1945 ternyata belum tercapai secara maksimal pasca 71 tahun Indonesia merdeka. Kemiskinan dan ketidakmerataan ekonomi masih menjadi masalah krusial bangsa ini. Pertumbuhan ekonomi Indonesia ternyata belum diikuti oleh pemerataan perekonomian masyarakat. Masih banyak masyarakat Indonesia yang menjadi pengangguran dan tidak memiliki modal untuk membuka usaha. Tidak bisa dipungkiri juga, bahwa financial exclusion yang terjadi di Indonesia merupakan salah satu efek dari sistem perbankan konvensional, salah satunya adanya sistem bunga. Bunga telah membelenggu masyarakat Indonesia sehingga mereka semakin sulit untuk mendapatkan akses keuangan. Karena persoalan inilah, implementasi financial inclusion di Indonesia menjadi penting.

Indonesia dan 19 negara lain yang tergabung dalam G20 telah sepakat perlunya peningkatan akses keuangan bagi masyarakat miskin khususnya di negara berkembang. Masyarakat miskin dimaksud adalah masyarakat yang berpendapatan rendah, berpenghasilan tidak tetap dan tidak dapat diprediksi. Sementara disisi lain mereka juga kekurangan produk dan jasa keuangan yang sesuai dengan kebutuhan mereka. Masyarakat miskin yang tidak terjangkau oleh perbankan atau disebut unbankable ini pada akhirnya terpinggirkan, tidak dapat melakukan kegiatan produksi secara optimal sehingga tidak memberikan sumbangan yang berarti bagi perekonomian. (Hartadi A. Sarwono, 2015). Sektor keuangan sebagai bagian dari penyokong perekonomian negara mempunyai tugas penting dalam mendukung kegiatan ekonomi masyarakat miskin agar mereka tetap dapat melakukan kegiatannya.

Pada KTT Pittsburgh bulan September 2009, para pemimpin G20 berkomitmen untuk meningkatkan akses pelayanan keuangan bagi masyarakat miskin. Disini diluncurkan G20 Financial Inclusion Experts Group (FIEG) dan juga menyepakati model Small and Medium Sized Enterprise (SME) untuk mendapatkan akses pembiayaan dari perbankan, serta memperkuat regulasi financial inclusion dan perlindungan konsumen (Demirguc Kunt and Leora Klapper, 2012). Pada KTT Toronto bulan Juni 2010, para pemimpin G20 menegaskan kembali komitmen mereka untuk meningkatkan akses layanan keuangan bagi masyarakat miskin dan meluncurkan G20 SME finance 
challenge. Pada KTT Toronto sektor swasta juga dihimbau ikut andil dalam mewujudkan financial inclusion. Para pemimpin G20 juga mendukung satu prinsip Inklusi Keuangan Inovatif, yang bertujuan untuk membentuk landasan dan rencana aksi pragmatis untuk meningkatkan akses layanan keuangan bagi masyarakat miskin (Demirguc Kunt and Leora Klapper, 2012).

Hasil kesepakatan dalam KTT negara G-20 menetapkan financial inclusion sebagai pilar penting dalam pembangunan ekonomi dan pengentasan kemiskinan di negara-negara anggotanya. Negara yang memiliki masalah terkait kemiskinan berupaya untuk menciptakan sistem keuangan yang inklusif. Hal ini menjadikan financial inclusion salah satu fokus pembangunan pada sektor keuangan di berbagai negara, karena sistem keuangan yang baik dapat mendorong pertumbuhan dan mengurangi kemiskinan.

Financial inclusion adalah proses untuk memastikan akses kredit yang tepat waktu dan memadai serta memberikan layanan keuangan kepada kelompok-kelompok yang berpendapatan rendah. Financial inclusion juga diartikan sebagai proses untuk memastikan akses produk dan layanan keuangan yang dibutuhkan oleh semua lapisan masyarakat pada umumnya dan kelompok-kelompok yang berpenghasilan rendah pada khususnya dengan biaya yang terjangkau secara adil dan transparan. (Rajalaxmi Kamath, 2007).

Financial inclusion bertujuan mendorong unbankable people untuk memiliki akses ke sistem keuangan formal, sehingga mereka memiliki kesempatan untuk mengakses jasa keuangan mulai dari tabungan, pembayaran, pembiayaan, asuransi, dan berbagai jasa keuangan lainnya (Alfred Hannig and Stevan Jansen, 2010). Tujuan lain darifinancial inclusion adalah agar setiap lapisan masyarakat, terutama rakyat menengah ke bawah dapat memiliki akses dengan mudah dalam memanfaatkan layanan jasa keuangan. Financial inclusion mempromosikan penghematan dan mengembangkan budaya menabung, meningkatkan akses kredit, baik kewirausahaan maupun konsumsi dan juga memungkinkan mekanisme pembayaran yang efisien, sehingga memperkuat basis sumber daya lembaga keuangan yang mampu memberikan manfaat ekonomi sebagai sumber daya dan tersedianya mekanisme pembayaran yang efisien dan alokatif (Kamalesh Shailesh C. Chakrobarty, 2011). Bukti empiris menunjukkan bahwa negara-negara dengan populasi penduduk yang besar, belum mempunyai akses yang luas terhadap lembaga keuangan 
formal dan juga menunjukkan rasio kemiskinan yang lebih tinggi dan ketimpangan yang lebih tinggi. Dengan demikian, financial inclusion hari ini bukanlah merupakan pilihan, tetapi menjadi sebuah keharusan dan perbankan merupakan pendorong utama untuk implementasi financial inclusion.

Keberadaan perbankan syariah sebagai perbankan yang beroperasional tanpa sistem bunga, diharapkan mampu menjadi garda depan pengimplementasian financial inclusion dan penghapusan financial exlusion. Masyarakat Indonesia yang mayoritas Muslim dan perkembangan perbankan syariah yang cukup signifikan, memberikan kita keyakinan bahwa perbankan syariah akan mampu menumpas financial exclusion.

Perbankan konvensional di Indonesia dengan sistem bunganya terbukti hancur saat krisis tahun 1998 dan bank syariah pada waktu itu, Bank Muamalat, dapat bertahan dari krisis. Ini merupakan sebuah fenomena yang menarik dan diikuti pula dengan perkembangan perbankan syariah yang cukup signifikan di Indonesia. Tetapi apakah jumlah perbankan syariah yang begitu banyak di Indonesia sudah menciptakan financial inclusion dan bagaimana perbankan syariah mengimplementasikan financial inclusion di Indonesia, serta apa yang menyebabkan terjadinya financial exclusion. Hal inilah yang ingin dibuktikan dalam penelitian ini.

\section{B. Metode}

Penelitian ini merupakan penelitian deskriptif dengan pendekatan kualitatif. Penelitian kualitatif adalah penelitian yang bermaksud untuk memahami fenomena tentang apa yang dialami oleh subjek penelitian dengan cara deskripsi dalam bentuk kata-kata dan bahasa, pada suatu konteks khusus yang alamiah dan dengan memanfaatkan berbagai metode alamiah (Lexy J. Maleong, 2000).

Data primer dalam penelitian ini berupa data hasil wawancara dari bank syariah mandiri dan Bank Tabungan Pensiun Nasional (BTPN) Syariah dan Bank Syariah Mandiri (BSM). Dua bank ini mewakili 13 Bank Umum Syariah yang ada di Indonesia. Bank Tabungan Pensiun Nasional (BTPN) Syariah merupakan representatif dari Bank Umum Syariah dengan asset terkecil dan Bank Syariah Mandiri (BSM) merupakan Bank Umum Syariah dengan asset terbesar. Data primer dalam penelitian ini juga berupa data funding dan financing bank syariah serta data tentang aksesibilitas bank syariah. 
Pada penelitian ini penulis mengambil data dari tahun 2014 sampai 2016. Sumber sekunder yang digunakan dalam penelitian ini adalah jurnal-jurnal ilmiah, buku-buku, artikel, dan berbagai sumber lain yang berkaitan dengan penelitian penulis.

Analisis kualitatif menggunakan teknik analisis data yang dikembangkan oleh Miles dan Huberman (2009), yaitu data reduction, data display, dan conclusion drawing/verivication. Sedangkan analisis kuantitatif dengan menggunakan Indeks keuangan Inklusif (IKI) berupa dimensi akses (access), penggunaan (usage) dan kualitas (quality) dari layanan perbankan. Penelitian ini menggunakan data primer berupa hasil wawancara dan data makroekonomi, terutama pada jangkauan layanan sektor perbankan. Data sekunder berupa laporan keuangan perbankan syariah tahun 2014-2016 dan hasil temuan dari berbagai sumber berupa data, jurnal, buku, dan lain sebagainya yang terkait dengan penelitian penulis.

\section{Pembahasan}

Ekslusi keuangan merupakan borgol bagi masyarakat miskin untuk memperoleh akses keuangan. Ekslusi keuangan menjadi hambatan bagi masyarakat miskin untuk bisa keluar dari kemiskinan. Praktek ekonomi ekslusif menjadi borgol kemiskinan dan pengangguran, sehingga dibutuhkan terobosan untuk menghasilkan kehidupan ekonomi yang inklusif. Sistem layanan keuangan inklusif sejatinya merupakan ikhtiar untuk menciptakan karakter kehidupan ekonomi yang tidak hanya mengakomodasi kalangan berada, namun juga memihak kalangan berpenghasilan rendah dan miskin (Nusron Wahid, 2014).

Istilah ekslusi keuangan (financial exclusion) pertama kali diciptakan pada tahun 1993 oleh seseorang yang konsen pada akses layanan perbankan (leyshon dan thrift, 1993). Pada tahun 1990an itu juga banyak penelitian yang membahas tentang akses masyarakat terhadap lembaga keuangan, baik itu perbankan, lembaga asuransi, dan kedit. Ada juga yang konsen dengan penyebab masyarakat yang tidak memiliki akses ke lembaga keuangan. Pada tahun 1999 istilah ekslusi keuangan digunakan secara lebih luas bagi mereka yang tidak bisa memiliki akses ke lembaga keuangan (Kempson dan whyley, 1999).

Andrew Leyshon dan Nigel Thrift mengatakan bahwa ekslusi keuangan mengacu pada proses-proses yang mencegah kelompokkelompok sosial yang kurang mampu dan kurang beruntung untuk 
mendapatkan akses sistem keuangan formal. Ini berimplikasi pada pembangunan yang tidak merata karena perbedaan geografis, pendapatan, dan pembangunan ekonomi (Andrew Leyshon dan Nigel Thrift, 1995). Andrew Leyson, et.al, menyatakan bahwa ekslusi keuangan merupakan proses yang mengacu kepada individu atau rumah tangga yang mempunyai kesulitan untuk mengakses layanan keuangan (Andrew Leyson, et.al, 2008). Ekslusi keuangan merupakan ketidakmampuan masyarakat untuk mendapatkan akses layanan keuangan. Adanya berbagai persyaratan pada lembaga keuangan membuat rakyat miskin tidak mampu untuk memperoleh dana dari lembaga keuangan, sehingga para kaum miskin menjadi kesulitan untuk keluar dari belenggu kemiskinan (Novia Nengsih, 2016).

Seseorang dianggap Ekslusi keuangan ketika mereka tidak memiliki akses ke beberapa atau semua layanan yang ditawarkan oleh lembaga keuangan utama di negara mereka tinggal atau tidak menggunakan layanan keuangan sama sekali. Studi penyediaan jasa keuangan dan pencegahan pengecualian keuangan' (Réseau Financement Alternatif 2008) menetapkan daftar layanan keuangan dasar dianggap penting untuk kehidupan sehari-hari, yaitu rekening bank untuk menerima penghasilan; rekening transaksi untuk melakukan pembayaran dari; rekening tabungan untuk menyimpan uang; dan akses ke kredit tanpa jaminan untuk mengelola kekurangan kas sementara dan biaya tak terduga. (Stefannie Lammermann, 2010). Seseorang yang ekslusi keuangan biasanya memiliki karakteristik sebagai berikut:

1. Tidak memiliki rekening bank atau jasa keuangan sejenis

2. Adanya ketergantungan pada bentuk-bentuk kredit alternatif seperti

renternir dan pegadaian

3. Kurangnya akses kepada produk keuangan utama lainnya seperti

asuransi, produk tabungan, dan pensiun

Indonesia termasuk negara dengan tingkat ekslusi keuangan cukup tinggi. Hal ini terlihat dari beberapa hasil survei dan penelitian yang dilakukan oleh beberapa lembaga nasional maupun internasional. Hasil survei lembaga Demografi FEUI tahun 2012, hanya 35,51\% penduduk dewasa Indonesia yang mempunyai rekening di lembaga keuangan formal. Survei tersebut sejalan dengan hasil survei rumah tangga Bank Indonesia tahun 2011 yang menunjukan bahwa hanya $48 \%$ penduduk Indonesia yang memiliki tabungan di bank dan lembaga 
keuangan non bank serta non lembaga keuangan/non formal (Novia Nengsih, 2016).

Ada banyak jenis dari ekslusi keuangan tersebut. World Bank menjelaskan bahwa ada empat area ekslusi keuangan, yaitu: Ekslusi Perbankan, ekslusi simpanan, ekslusi pembiayaan, dan ekslusi asuransi (World Bank, 1995). Dalam penelitian ini kita hanya membahas tiga hal saja yang berkaitan dengan pembahasan ini.

Akses ke perbankan (layanan transaksi perbankan khususnya) dipandang sebagai kebutuhan universal dalam masyarakat. Kurangnya akses perbankan memberikan efek buruk sehingga inklusi keuangan menjadi rusak, padahal akses perbankan adalah kunci untuk mengakses layanan keuangan lainnya (kredit / tabungan). Kurangnya akses perbankan juga mengganggu akses pasar dan memberikan kesempatan ketidakadilan untuk tumbuh dan akibatnya dapat meningkatkan risiko kemiskinan. Orang-orang yang tidak memiliki akses ke perbankan akan sangat rentan dengan pencurian karena mereka suka melakukan penyimpanan uang cash (European Commission, 2008). Ada beberapa tingkatan masyarakat untuk mengidetifikasi apakah seseorang itu ekslusif atau inklusif terhadap perbankan:

a. Unbanked adalah mereka yang benar-benar tidak memiliki akses terhadap perbankan sama sekali.

b. Marginally Banked adalah orang-orang yang memiliki akun deposito di perbankan tetapi tidak menggunakan fasilitas pembayaran elektronik. Perbankan memberikan kesempatan kepada masyarakat untuk mengakses perbankan, tetapi hanya sedikit yang menggunakan fasilitas tersebut bahkan ada yang sama sekali tidak menggunakan.

c. Fully Banked adalah orang yang memiliki akses ke berbagai layanan perbankan yang sesuai dengan kebutuhan dan status sosial ekonomi mereka.

Masalah yang berkaitan dengan tabungan benar-benar berbeda. Akses terhadap tabungan kelihatannya sederhana dan tidak kelihatan membawa banyak masalah. Selain itu, kurangnya akses atau Penggunaan dapat membawa ketidaknyamanan dalam kehidupan sehari-hari, tetapi tidak berhubungan dengan ekslusi sosial. Namun demikian, beberapa masalah sosial telah diidentifikasi terkait dengan ekslusi rekening tabungan 
a. Kurangnya dokumen identifikasi (relevan untuk transaksi perbankan juga)

b. Pemilikan rekening tidak membawa keuntungan yang signifikan (karena biaya dan kompleksitas prosedur / kontrak).

Pembiayaan merupakan hal yang sangat penting dalam akses terhadap perbakan, karena pembiayaan berperan penting dalam penyediaan modal bagi masyarakat sehingga bias meningkatkan produktifitasnya dan pada akhirnya bisa mempermudah mereka untuk memperoleh barang dan jasa sebagai pemenuhan kebutuhan. Pembiayaan ini memainkan peran besar dalam mempengaruhi konsumsi dan pendapatan seseorang. Kurangnya akses terhadap pembiayaan ini dapat mempengaruhi inklusi sosial dengan berbagai cara:

a. Kurangnya akses ke berbagai produk pembiayaan berdampak terhadap standar hidup minimum. Kurangnya pembiayaan yang tepat dapat mengurangi kesejahteraan tingkat dan harga diri;

b. Kurangnya akses ke pembiayaan yang sesuai dapat menyebabkan masalah baru, seperti meningkatkan anggaran rumah tangga ketidakseimbangan dalam jangka waktu yang panjang dan akhirnya dapat menyebabkan over-hutang. Over hutang dapat menyebabkan ekslusi keuangan dan ekslusi sosial.

Perbankan syariah di Indonesia sejak berdirinya Bank Muamalat tahun 1992 sampai sekarang terus mengalami pertumbuhan yang signifikan. Namun perkembangan perbankan syariah yang cukup signifikan tersebut ternyata masih menimbulkan sejumlah PR bagi pemerintah. Sampai saat ini market share perbankan syariah belum menembus angka 5\%. Dalam artian bahwa sangat tidak relevan ketika perbankan syariah dikomparasikan dengan perbankan konvensional yang memang sudah lama berkembang di Indonesia. Market share yang masih di bawah 5\% ini tentunya berimplikasi pada sedikitnya masyarakat yang bisa dilayani oleh perbankan syariah.

Kurangnya akses masyarakat terhadap perbankan syariah tidak melulu dikarenakan ketidaktahuan masyarakat terhadap perbankan syariah. Melihat persoalan ini penulis mengidentifikasi penyebab ekslusi keuangan berdasarkan indicator world Bank (2008), yaitu dari sisi nasabah (permintaan) dan dari sisi perbankan (penawaran). Identifikasi ini lahir atas dasar penelitian terhadap Bank Syariah Mandiri dan Bank Tabungan Pensiunan Nasional Syariah. 
Ada beberapa hal yang menyebabkan seseorang menjadi tidak terakses oleh perbankan syariah (ekslusi keuangan), yaitu:

1. Permintaan (Nasabah)

Otoritas Jasa Keuangan (OJK) menyatakan saat ini, total nasabah perbankan syariah mencapai sekitar 15 juta jiwa. Sementara itu, nasabah perbankan konvensional menyentuh sekitar 80 juta orang. Dibandingkan dengan bank konvensional, total nasabah bank syariah baru mencapai 18,75 persen (OJK, 2015). Kalau dibanding dengan perbankan konvensional, total nasabah perbankan syariah memang masih lebih kecil. Namun, sejauh ini pertumbuhan nasabah di industri bank syariah rata-rata mencapai kisaran 15-20 persen. Masih tingginya angka ekslusi keuangan nasabah perbankan syariah disebabkan beberapa hal berikut:

a. Pengetahuan tentang perbankan syariah

Jauhnya akses terhadap perbankan serta kurangnya sosialisasi dari perbankan membuat pengetahuan masyarakat terhadap perbankan syariah sangat kurang (Marsini, nasabah BTPNS, 2016). Ketidaktahuan masyarakat ini juga tidak terlepas dari rendahnya pendidikan masyarakat di daerah tersebut.

b. Pendapatan

Pendapatan seseorang akan berpengaruh terhadap aktivitas ekonominya. Seseorang dengan pendapatan rendah tidak mengakses perbankan karena memang tidak memiliki uang untuk disimpan dan tidak bisa mengajukan pinjaman (syofyan, Nasabah BSM, 2016). Pendapatan yang rendah menyebabkan masyarakat tidak bisa mengakses perbankan syariah.

c. Tidak adanya jaminan (collateral)

Di perbankan syariah masalah ini sebenarnya sudah mulai teratasi karena sudah ada bank syariah, yaitu BTPN Syariah yang mampu memberikan pembiayaan tanpa agunan. Tetapi memang belum semua perbankan syariah di Indonesia melakukan ini.

2. Penawaran (Bank)

Dari hasil penelitian yang penulis lakukan, setidaknya dari sisi penawaran (bank) teridentifikasi ada 7 penyebab masyarakat ekslusi keuangan, yaitu:

a. Jarak kantor yang jauh dengan tempat tinggal 
Akses keuangan tertutup lantaran jarak antara masyarakat dengan lembaga keuangan yang sulit dijangkau. Lokasi bank lebih banyak di pusat kota sedangkan masyarakat yang membutuhkan layanan keuangan berada di daerah. Hal ini menyebabkan tejadinya gap antara perkotaan dan pedesaan. Masyarakat desa akan selalu kesulitan dalam mendapatkan akses keuangan.

Menyikapi persoalan ini, sebenarnya dua tahun belakangan OJK telah mencoba meminimalisir 'gap' itu dengan meluncurkan programbranchless banking atau layanan bank tanpa kantor. Program yang lebih dikenal dengan Layanan Keuangan Tanpa Kantor dalam Rangka Keuangan Inklusif (Laku Pandai). Layanan Keuangan Tanpa Kantor Dalam Rangka Keuangan Inklusif atau yang disebut dengan Laku Pandai adalah salah satu program yang digunakan pemerintah dalam meningkatkan taraf hidup masyarakat dengan meningkatkan akses dan pengetahuan serta permudahan layanan keuangan dalam jasa perbankan. Laku Pandai diselenggarakan oleh semua lembaga jasa keuangan, salah satunya adalah bank. Bank bekerjasama dengan agen sebagai kepanjangan tangan bank dalam melakukan transaksi layanan keuangan (Novia Nengsih, 2016). Ini menjadi cara untuk mengurangi masalah jarak antara lembaga keuangan dengan yang membutuhkan layanan keuangan. Bahkan hingga tahun 2015 ini, agen-agen Laku Pandai sudah mencapai 30.000 agen dari beberapa bank pendukung program ini.

Di Indonesia, branchless banking menjadi salah satu kebijakan penting dalam rangka mendukung pengimplementasian financial inclusion. Bank Indonesia tahun 2013 meluncurkan program branchless banking dalam kerangka besar sebagai salah satu kegiatan financial inclusion. Dengan dukungan inovasi delivery channel Branchless Banking, pangsa pasar untuk unbanked people akan menjadi target bisnis yang menarik bagi perbankan di Indonesia. Disamping itu, dukungan kondisi geografis dan kondisi masyarakat Indonesia, branchless banking diharapkan akan dapat mendukung perluasan akses layanan jasa keuangan bagi masyarakat (Pungky Purnomo Wibowo, 2013). 
b. Prosedur yang rumit

Perbankan memiliki prosedur tersendiri dalam menilai kelayakan pemberian pembiayaan kepada nasaah. Prosedur perbankan suka berbelit-belit dan rumit, sehingga membuat para nasabah menjadi bosan dan beralih mencari pinjaman alternative dari pihak lain (Nofri, 2016). Prosedur yang rumit menjadi penyebab ekslusi keuangan masyarkat, sehingga perbankan perlu melakukan penyederhanaan terhadap proses pembiayaan.

c. Ketidaksesuaian produk dengan kebutuhan

Produk yang ada diperbankan sering tidak sinkron dengan kebutuhan masyarakat. Persoalan ini banyak tejadi dalam pinjaman konsumtif. Banyak masyarakat yang membutuhkan pinjaman konsumtif seperti biaya pendidikan anaknya, membeli kendaraan, dan kebutuhan konsumtif lainnya. Pembiayan produktif perbankan syariah juga sangat sedikit yang membiayai bidang pertanian, padahal mayoritas pencarian masyarakat Indonesia adalah bidang pertanian. Ketidaksesuain produk perbankan dengan kebutuhan masyarakat ini menjadikan masyarakat Indonesia tidak bisa keluar dari ekslusi keuangan.

d. Bahasa yang tidak efektif

Bahasa yang efektif adalah ketika maksud pembicaraan bisa sampai kepada komunikan sesuai dengan maksud komunikator. Dalam dunia perbankan komunikasi efektif harus terjadi antara pihak bank dengan nasabah. Hal ini sangat dipengaruhi oleh kualitas Sumber Daya Manusia perbankan. SDM yang tidak berkualitas akan menyebabkan komunikasi tidak efektif dan akhirnya nasabah menjadi enggan berurusan dengan pihak bank.

e. Perilaku pegawai

Layanan perbankan meupakan kunci utama keberlangsungan perbankan. Layanan perbankan akan sangat terkait dengan perilaku pegawai, sehingga pelayan menjadi prioritas utama perbankan. Meskipun begitu masih banyak terjadi perilaku pegawai perbankan yang tidak menyenangkan nasabah sehingga nasabah memilih untuk tidak mengakses perbankan lagi. 
f. Waktu operasi bank

Waktu operasi perbankan yang terbatas juga menjadi masalah terjadinya ekslusi keuangan. Banyak masyarakat yang tidak bisa datang ke perbankan diakibatkan aktivitas pekerjaan mereka. Sehingga system jemput bola merupakan salah satu solusi meminimalisir ekslusi keuangan.

g. Technical innovation

Layanan keuangan berbasis teknologi atau fintech berperan besar dalam peningkatan inklusi keuangan. Fintech harus mendorong lebih efisiennya layanan jasa keuangan bagi seluruh lapisan masyarakat. Muliaman D. Hadad (ketua OJK) mengatakan bahwa Fintech dapat dikembangkan untuk merangkul jutaan masyarakat Indonesia untuk masuk ke dalam sektor jasa keuangan, melalui penyediaan kemudahan akses terhadap berbagai produk-produk keuangan yang disesuaikan dengan karakteristik masyarakat (Muliaman D. Hadad, 2016). Perbankan syariah perlu mengembangkan teknologi untuk meningkatkan inklusi keuangan.

Financial inclusion sebenarnya ada untuk meminimalisir financial exclusion. Melihat rendahnya tingkat akses jasa keuangan Indonesia, maka isu inklusi keuangan menjadi sangat relevan untuk dimunculkan dan dioptimalkan. Dengan struktur pelaku usaha dalam perekonomian Indonesia yang didominasi oleh unit usaha mikro dan kecil yang mencapai 51,2 juta unit atau mencapai $99,91 \%$ dari pelaku usaha di Indonesia (Data Kementerian Koperasi dan UMKM), maka tentu saja isu inklusi keuangan ini diharapkan sektor keuangan mampu menjawab dan melayani kebutuhan akses jasa keuangan segmen raksasa (dominan) sektor usaha Indonesia ini.

Dalam Strategi Nasional Keuangan Inklusif (SNKI), inklusi keuangan didefinisikan sebagai hak setiap orang untuk memiliki akses dan layanan penuh dari lembaga keuangan secara tepat waktu, nyaman, informatif, dan terjangkau biayanya, dengan penghormatan penuh kepada harkat dan martabatnya. Layanan keuangan tersedia bagi seluruh segmen masyarakat, dengan perhatian khusus kepada orang miskin, orang miskin produktif, pekerja migran, dan penduduk di daerah terpencil (Bank Indonesia, 2014). Giovanna Priale Reyes (2015) mengatakan bahwa financial inclusion berarti mayoritas penduduk memiliki akses yang luas untuk portofolio produk dan layanan keuangan berkualitas yang meliputi pinjaman, layanan deposito, 
asuransi, pensiun dan sistem pembayaran, serta pendidikan keuangan dan mekanisme perlindungan konsumen. V. Leeladhar (2015) juga memberikan pemikirannya bahwa financial inclusion merupakan pemberian layanan perbankan dengan harga yang terjangkau untuk sebagian besar kelompok berpendapatan rendah. Layanan perbankan baik dalam funding, financing, maupun jasa ke seluruh penduduk tanpa diskriminasi adalah tujuan utama dari financial inclusion. Dalam penelitian ini penulis menggunakan defenisi Inklusi keuangan adalah proses untuk memberikan akses layanan keuangan formal kepada unbankable people. Unbankable people merupakan kelompok masyarakat yang kurang beruntung yang belum tersentuh atau belum memiliki akses kepada layanan keuangan formal.

Inklusi keuangan bertujuan mendorong unbankable people untuk memiliki akses ke sistem keuangan formal, sehingga mereka memiliki kesempatan untuk mengakses jasa keuangan mulai dari tabungan, pembayaran, pembiayaan, asuransi, dan berbagai jasa keuangan lainnya (Alfred Hannig and Stevan Jansen, 2010). Tujuan lain dari inklusi keuangan adalah agar setiap lapisan masyarakat, terutama rakyat menengah ke bawah dapat memiliki akses dengan mudah dalam memanfaatkan layanan jasa keuangan. Kemudahan akses masyarakat terhadap sistem perbankan akan meningkatkan pertumbuhan ekonomi negara. Inklusi keuangan juga bertujuan untuk mengurangi kesenjangan sosial, menyelamatkan masyarakat kecil dari jerat utang kepada rentenir akibat tidak adanya akses terhadap lembaga keuangan di wilayah sekitar mereka, serta meningkatkan kesejahteraan masyarakat miskin melalui peningkatan kemampuan individu dalam mengelola keuangannya. Dalam hal ini, Bank Indonesia mengeluarkan 23 butir kebijakan yang meliputi lima aspek, yakni kebijakan penguatan stabilitas moneter, kebijakan mendorong peran intermediasi perbankan, kebijakan meningkatkan ketahanan perbankan, penguatan kebijakan makro prudensial, serta penguatan fungsi pengawasan (Deasy Puspita Rini, 2015).

Makin meluasnya jangkauan perbankan syariah menunjukkan peran perbankan syariah makin besar untuk pembangunan perekonomian Indonesia. Perbankan syariah akan tampil sebagai garda terdepan atau lokomotif terwujudnya inklusi keuangan. Ini pula yang menjadi misi dasar dan utama syariah, yakni pengentasan kemiskinan dan pembangunan kesejahteraan seluruh lapisan masyarakat (Novia Nengsih, 2016). 
Optimisme ini dibangun berdasarkan beberapa faktor. Pertama, bank syariah lebih dekat kepada sektor rill karena produk yang ditawarkan khususnya dalam pembiayaan, senantiasa menggunakan underlying transaksi di sektor ril, sehingga dampaknya lebih lebih nyata dalam mendorong pertumbuhan ekonomi. Kedua, tidak terdapat produk-produk yang bersifat spekulatif (gharar), sehingga mempunyai daya tahan yang kuat dan teruji ketangguhannya dari krisis keuangan global. Secara makro, perbankan syariah dapat memberikan daya dukung terhadap terciptanya stabilitas sistem keuangan dan perekonomian nasional. Ketiga, sistem bagi hasil (profit-loss sharing) yang menjadi ruh perbankan syariah akan membawa manfaat yang lebih adil bagi semua pihak, baik bagi pemilik dana selaku deposan, pengusaha selaku debitor maupun pihak bank selaku pengelola dana (Hendy Herijanto, 2013).

Tahun 2014 merupakan tahun yang diwarnai dengan harapan dan impian baru bagi Indonesia. Dengan terpilihnya presiden baru dan kebijakan keuangan yang baru memberikan tantangan tersendiri bagi sektor perbankan dalam mengembangkan diri. Sampai saat ini perkembangan bank syariah di Indonesia sudah menunjukan peningkatan yang baik. Berdasarkan laporan Otoritas Jasa Keuangan (OJK) pertumbuhan bank syariah beranjak naik, dengan rasio kecukupan modal mencapai 15,7\%, meningkat dari tahun 2013 yang hanya menembus angka 14,4\%. Namun, seperti yang kita ketahui bersama, tantangan terbesar bagi perbankan syariah di Indonesia pada 2014 adalah likuiditas. Ketatnya likuiditas sudah terlihat dari pertumbuhan Dana Pihak Ketiga (DPK) yang melambat sejak dua tahun terakhir. Pada penelitian ini, penulis memfokuskan penelitian pada dua bank umum syariah, yaitu Bank Syariah Mandiri dan Bank Tabungan Pensiunan Nasional Syariah. Implementasi inklusi keuangan di perbankan syariah ini difokuskan untuk melihat sosialisasi inklusi keuangan oleh perbankan syariah, simpanan di perbankan syariah dan pembiayaan mikro syariah.

\section{Sekilas profil Bank Syariah Mandiri (BSM) dan Bank Tabungan Pensiunan Nasional Syariah (BTPN Syariah) Bank Syariah Mandiri (BSM)}

BSM hadir sejak tahun 1999. Kehadiran BSM ini sesungguhnya merupakan hikmah sekaligus berkah pasca krisis ekonomi dan moneter 1997-1998. Sebagaimana diketahui, krisis ekonomi dan 
moneter sejak Juli 1997, yang disusul dengan krisis multidimensi termasuk di panggung politik nasional, telah menimbulkan beragam dampak negatif yang sangat hebat terhadap seluruh sendi kehidupan masyarakat, tidak terkecuali dunia usaha. Dalam kondisi tersebut, industri perbankan nasional yang didominasi oleh bank-bank konvensional mengalami krisis luar biasa. Pemerintah akhirnya mengambil tindakan dengan merestrukturisasi dan merekapitalisasi sebagian bank-bank di Indonesia.

Salah satu bank konvensional, PT Bank Susila Bakti (BSB) yang dimiliki oleh Yayasan Kesejahteraan Pegawai (YKP) PT Bank Dagang Negara dan PT Mahkota Prestasi juga terkena dampak krisis. BSB berusaha keluar dari situasi tersebut dengan melakukan upaya merger dengan beberapa bank lain serta mengundang investor asing. Pada saat bersamaan, pemerintah melakukan penggabungan (merger) empat bank (Bank Dagang Negara, Bank Bumi Daya, Bank Exim, dan Bapindo) menjadi satu bank baru bernama PT Bank Mandiri (Persero) pada tanggal 31 Juli 1999. Kebijakan penggabungan tersebut juga menempatkan dan menetapkan PT Bank Mandiri (Persero) Tbk. sebagai pemilik mayoritas baru BSB.

Sebagai tindak lanjut dari keputusan merger, Bank Mandiri melakukan konsolidasi serta membentuk Tim Pengembangan Perbankan Syariah. Pembentukan tim ini bertujuan untuk mengembangkan layanan perbankan syariah di kelompok perusahaan Bank Mandiri, sebagai respon atas diberlakukannya UU No. 10 tahun 1998, yang memberi peluang bank umum untuk melayani transaksi syariah (dual banking system).

Perubahan kegiatan usaha BSB menjadi bank umum syariah dikukuhkan oleh Gubernur Bank Indonesia melalui SK Gubernur BI No. 1/24/ KEP.BI/1999, 25 Oktober 1999. Selanjutnya, melalui Surat Keputusan Deputi Gubernur Senior Bank Indonesia No. 1/1/KEP.DGS/ 1999, BI menyetujui perubahan nama menjadi PT Bank Syariah Mandiri. Menyusul pengukuhan dan pengakuan legal tersebut, PT Bank Syariah Mandiri secara resmi mulai beroperasi sejak Senin tanggal 25 Rajab $1420 \mathrm{H}$ atau tanggal 1 November 1999. 
PT Bank Syariah Mandiri hadir, tampil dan tumbuh sebagai bank yang mampu memadukan idealisme usaha dengan nilai-nilai rohani, yang melandasi kegiatan operasionalnya. Harmoni antara idealisme usaha dan nilai-nilai rohani inilah yang menjadi salah satu keunggulan Bank Syariah Mandiri dalam kiprahnya di perbankan Indonesia. BSM hadir untuk bersama membangun Indonesia menuju Indonesia yang lebih baik.

\section{Bank Tabungan Pensiunan Nasional Syariah (BTPN Syariah)}

BTPN Syariah adalah Bank Umum Syariah ke 12 di Indonesia yang memiliki tekad untuk menumbuhkan jutaan rakyat Indonesia sehingga memiliki kehidupan yang lebih baik. Melalui produk dan aktivitasnya, BTPN Syariah senantiasa mengajak dan melibatkan seluruh stakeholders untuk bersama-sama memberikan kemudahan akses masyarakat dalam menggunakan atau memanfaatkan produk dan layanan jasa bank (financial inclusion), memberikan informasi, serta kegiatan pemberdayaan yang berkelanjutan dan terukur.

BTPN Syariah lahir dari perpaduan dua kekuatan yaitu, PT Bank Sahabat Purbadanarta dan Unit Usaha Syariah BTPN. Bank Sahabat Purbadanarta yang berdiri sejak Maret 1991 di Semarang, merupakan bank umum non devisa yang $70 \%$ sahamnya diakusisi oleh PT Bank Tabungan Pensiunan Nasional, Tbk (BTPN), pada 20 Januari 2014, dan kemudian dikonversi menjadi BTPN Syariah berdasarkan Surat Keputusan Otoritas Jasa Keuangan (OJK) tanggal 22 Mei 2014.

Unit Usaha Syariah BTPN yang difokuskan melayani dan memberdayakan keluarga pra sejahtera di seluruh Indonesia adalah salah satu segmen bisnis di PT Bank Tabungan Nasional Tbk sejak Maret 2008, kemudian di spin off dan bergabung ke BTPN Syariah pada Juli 2014.

\section{Sosialisasi inklusi keuangan perbankan syariah (Marketing Strategy)}

Penelitian Otoritas Jasa keuangan (OJK) tahun 2013 melalui survei di 20 provinsi dengan 8.000 responden, mengungkap relatif rendahnya literasi (pemahaman) keuangan masyarakat Indonesia. Kondisi ini sejalan dengan rendahnya 
tingkat inklusi keuangan warga. Dalam hal literasi, tingkat pemahaman masyarakat atas perbankan sekitar 22 persen, jasa asuransi 18 persen, pegadaian 15 persen, lembaga pembiayaan 7 persen, dan pasar modal 4 persen. Hasil-hasil ini mengandung pesan bahwa tidak ada pilihan lain bagi bangsa Indonesia kecuali membuat program dan kebijakan untuk meningkatkan akses keuangan bagi masyarakat miskin, yakni program dan kebijakan yang dapat menjadi solusi bagi rumah tangga miskin yang kesulitan mendapatkan dukungan kredit dari lembaga keuangan formal.

Perbankan syariah mencoba membantu menyelesaikan masalah tersebut. Bank Syariah Mandiri sebagai salah satu bank umum syariah di Indonesia memiliki strategi marketing sendiri agar bisa memberikan akses keuangan kepada masyarakat Indonesia. Melalui produk-produknya BSM selalu berusaha untuk memenuhi kebutuhan nasabah. Strategi marketing berupa marketing mix (4P: Price, Product, Promotion, ) selalu dilakukan demi kepentingan nasabah. Yang menarik dari marketing yang dilakukan BSM adalah system jemput bola, sehingga nasabah tidak perlu susah-susah lagi untuk mendatangi pebankan.

Kelahiran BTPN Syariah pada Juli 2014 memberikan warna dan harapan baru pada segmen keluarga pra-sejahtera di Indonesia. Pendekatan Bisnis yang digunakan oleh BTPN Syariah ini menggunakan prinsip financial inclusion dalam rangka ikut memberdayakan keluarga pra/cukup sejahtera untuk kehidupan yang lebih baik.

BTPN Syariah juga melakukan system jemput bola, tetapi ada yang menarik dengan system yang diterapkan BTPN Syariah, yaitu pada system pembiayaan. BTPN syariah memiliki Paket Masa Depan (PMD) pada produk pembiayaannya. Paket Masa Depan (PMD) adalah produk yang dikhususkan untuk mendukung implementasi inklusi keuangan. Paket Masa Depan (PMD) diperuntukkan bagi para perempuan dengan basis kelompok. Pembiayaan ini diberikan tanpa agunan dan diperbolehkan bagi nasabah yang baru mau mulai membuka usaha. Pembayaran pembiayaan ini dilakukan setiap minggu selama satu tahun dan platfond pembiayaannya bisa naik $100 \%$ pada tahun berikutnya. BTPN syariah selalu intens melakukan 
monitoring dan evaluasi terhadap keberlangsungan usaha nasabahnya.

BTPN syariah dalam melakukan operasionalnya menerapkan 3 pilar daya Program Daya yang merupakan program utama BTPN syariah. Tiga pilar inilah yang menjadi keunikan BTPN syariah. Tiga pilar utama tersebut adalah:

a. Kesehatan (Daya Sehat Sejahtera)

b. Pengembangan Usaha (Daya tumbuh Usaha), dan

c. Komunitas (Daya Tumbuh Komunitas).

\section{Simpanan ramah nasabah}

Simpanan ramah nasabah yang penulis maksudkan disini adalah produk simpanan yang sesuai dengan kebutuhan nasabah. Bank Syariah Mandiri (BSM) menawarkan berbagai macam produk simpanan kepada nasabah. Pada produk tabungan BSM memiliki produk tabungan BSM, BSM tabungan berencana, BSM tabungan simpatik, BSM tabungan investa cendikia, BSM tabungan dolar, BSM tabungan pension, dan BSM tabunganku. Pada produk giro, BSM memiliki produk BSM giro, BSM giro valas, BSM giro Singapura dolar, dan BSM giro Euro. Pada produk deposito BSM memiliki BSM deposito dan BSM deposito valas.

BTPN Syariah juga menawarkan bemacam produk simpanan kepada nasabah, yaitu: tabungan citra $\mathrm{iB}$, tabungan Taseto iB, deposito $\mathrm{iB}$, giro $\mathrm{iB}$, taseto mapan iB. Fokus pada pemberdayaan nasabah pra-sejahtera produktif, BTPN Syariah memiliki dua produk Utama Pendanaan dan Pembiayaan. Kedua produk tersebut semata-mata ditujukan untuk memberdayakan keluarga pra-sejahtera produktif. Produk Pendanaan memberikan kesempatan kepada Nasabah untuk menumbuhkan perekonomian jutaan rakyat Indonesia. Nasabah tidak hanya mendapatkan kenyamanan bertransaksi perbankan dan imbal hasil optimal, namun memiliki kesempatan membantu keluarga pra/cukup sejahtera di seluruh Indonesia untuk memperoleh hidup yang lebih baik.

\section{Pembiayaan mikro perbankan syariah}

Pembiayaan (financing) merupakan salah satu tugas pokok bank, yaitu memberikan fasilitas penyediaan dana untuk 
memenuhi kebutuhan pihak-pihak yang merupakan defisit unit. Di Indonesia, penggunaan pinjaman lebih rendah dibandingkan saving. Lebih kurang 60 persen dari populasi Indonesia mempunyai akses pinjaman tetapi masyarakat lebih banyak memperoleh pinjaman dari sektor informal seperti keluarga, teman, tetangga, dan lainnya. Kredit bank hanya mengkover sekitar 17 persen dari populasi Indonesia. Alasan umum tidak meminjam melalui perbankan adalah ketidaksanggupan masyarakat dalam memenuhi collateral/jaminan (NSFI, 2012). Bank syariah merupakan bank yang sangat produktif dan memberikan akses pembiayaan yang luas kepada masyarakat. Hal ini terbukti dengan Financing to Deposit Ratio (FDR) bank syariah yang tinggi sebagaimana table di bawah ini.

Miliar Rupiah (in Billion IDR)

\begin{tabular}{l} 
Tabel 3.11 Financing to Deposit Ratio (FDR) Bank Umum Syariah dan Unit Usaha Syariah - Maret \\
2015 \\
(Percentage of FDR Islamic Comercial Bank and Islamic Business Unit) \\
\hline \\
\hline
\end{tabular}

Sumber: Otoritas Jasa Keuangan (OJK), Statistik Perbankan Syariah, Maret 2015. (Data diolah)

Dari tabel diatas terlihat bahwa FDR Bank Umum Syariah dan Unit Usaha Syariah baik, yaitu berada di bawah 110 persen sesuai ketentuan pemerintah. Ini menunjukkan bahwa dana yang disimpan masyarakat pada Bank Umum syariah dan Unit Usaha Syariah benarbenar disalurkan kepada sektor rill. Dana masyarakat benar-benar diproduktifitaskan, berarti bank telah menjalankan fungsinya dengan baik sebagai lembaga intermediari. Efeknya adalah terjadinya aliran dana dari pihak yang kelebihan dana kepada pihak yang membutuhkan dana. Hal ini akan meningkatkan produktifitas dan perekonomian masyarakat.

Bank Syariah Mandiri (BSM) merupakan salah satu bank umum syariah yang konsen pada pemberian akses pembiayaan bagi masyarakat. Pembiayaan BSM tumbuh signifikan pada lima tahun terakhir yaitu 2010-2015. Tahun 2010 mengalami kenaikan sebesar 44,39\%, tahun 2011 naik 53,23\%, tahun 2012 mengalami kenaikan 
21,84, dan tahun 2013 naik 12,76\%, tahun 2014 memang sedikit mengalami pertumbuhan negatif sebesar 2,6\% disebabkan karena perlambatan ekonomi global. BSM menguasai pembiayaan dengan pangsa rata-rata 30,76 persen dibanding pembiayaan perbankan syariah nasional (Novia Nengsih, 2016).

Pentingnya memberdayakan usaha kecil merupakan tantangan sekaligus peluang untuk meningkatkan portofolio pembiayaan di segmen tersebut. Pada 2014, BSM telah berhasil menyalurkan pembiayaan usaha mikro dan kecil sebesar Rp8,54 triliun atau 99,08\% terhadap jumlah penyaluran pembiayaan usaha mikro dan kecil pada 2013 sebesar Rp8,62 triliun. Pembiayaan terhadap sektor usaha mikro dan kecil memiliki makna yang penting bagi BSM dalam kontribusi membangun negeri melalui peningkatan pemberdayaan masyarakat. Salah satu bentuk pembiayaan pada sektor usaha mikro dan kecil yang telah dilakukan Bank adalah BSM Pembiayaan Warung Mikro (sustainability BSM tahun 2014).

Warung Mikro BSM adalah layanan pembiayaan di kantor cabang dan cabang pembantu untuk nasabah kategori mikro. Plafon maksimum yang diberikan kepada nasabah melalui warung mikro BSM adalah Rp200 juta sesuai dengan rata-rata maksimum kebutuhan usaha mikro saat ini. Sampai dengan akhir 2014, outlet Warung Mikro yang telah dibuka berjumlah 456 outlet dan 30 Unit Kantor Area Mikro tersebar di seluruh wilayah Indonesia. BSM menyalurkan pembiayaan melalui warung mikro selama 2014 mencapai Rp2,02 triliun, tumbuh sebesar sebesar Rp92,7 miliar terhadap pembiayaan warung mikro pada 2013 sebesar Rp1,93 triliun.

Berbeda dengan eksistensi bank syariah lainnya, BTPN Syariah memberi perhatian pada pemberdayaan nasabah perempuan dari keluarga pra-sejahtera di pedesaan. Caranya memberikan program pembiayaan yang digabung dengan program pemberdayaan. Program terintegrasi ini memberikan kesempatan kepada kelompok-kelompok nasabah perempuan untuk mendapatkan akses, produk, layanan perbankan serta program pemberdayaan dengan membangun empat perilaku unggul, yakni: Berani Berusaha, Disiplin, Kerja Keras dan Saling Bantu (BDKS). Memberikan perhatian pada pemberdayaan perempuan inilah, menjadi keunikan tersendiri yang dimiliki oleh BTPN Syariah. Dengan mengemban visi "Menjadi Bank Syariah Terbaik untuk Keuangan Inklusif, Mengubah Hidup Berjuta Rakyat Indonesia", keunikan tersebut menjadi keunggulan BTPN Syariah yang 
tidak dimiliki bank berbasis syariah lainnya di Indonesia. Sehingga, bila dilihat secara seksama, keunikankeunikan yang dimiliki BTPN Syariah antara lain; Pertama, satu-satunya bank syariah di Indonesia yang menerapkan prinsip keuangan inklusif (Financial Inclusion) melayani segmen keluarga pra-sejahtera produktif yang selama ini bukan merupakan segmen utama bank. Kedua, satu-satunya bank yang memprioritaskan pada pemberdayaan perempuan. Ketiga, satusatunya bank yang lebih dari 90\% karyawannya adalah wanita. Keempat, satusatunya bank yang memberikan kesempatan kepada ribuan tamatan SMA untuk membangun karir di bank. Kelima, bank yang mampu melahirkan generasi karyawan bank baru, yaitu karyawan bank yang melayani golongan masyarakat pra-sejahtera (productive poor banker), dimana karyawan ini kami sebut Melati Putih Bangsa.

Dalam rangka implementasi inklusi keuangan, BTPN Syariah memiliki pembiayaan Paket Masa Depan (PMD), yaitu program terpadu BTPN Syariah yang diberikan kepada sekelompok wanita di pedesaan yang ingin berusaha dan memiliki impian untuk merubah hidup, tetapi tidak memiliki akses ke layanan perbankan. Dengan mengedepankan empat perilaku efektif dalam menggapai mimpi mereka yaitu Berani Berusaha, Disiplin, Kerja Keras, dan Saling Bantu, BTPN Syariah secara rutin melakukan program pemberdayaan yang berkelanjutan dan terukur. PMD merupakan pinjaman senilai Rp $1-3$ juta yang dibayarkan melalui cicilan setiap dua minggu dalam waktu satu tahun. Di akhir periode, nasabah dapat menerima pembiayaan dengan jumlah yang lebih besar $100 \%$ dari plafond semula. PMD mencakup empat elemen yakni: memberikan solusi keuangan, perencanaan keuangan sederhana, partisipasi kelompok dan melibatkan karyawan BTPN untuk bertindak sebagai fasilitator dan menjadai teladan bagi nasabah BTPN Syariah (Anggia Yuliandra, 2016).

Paket Masa Depan (PMD) merupakan instrumen baru dan inovatif yang dimunculkan oleh BTPN Syariah. Menurut penulis ini merupakan sebuah terobosan baru yang luar biasa yang dilakukan oleh BTPN Syariah, karena baru BTPN Syariah yang berani memberikan pembiayaan tanpa agunan dan berani memberikan pembiayaan kepada nasabah yang akan membuka usaha (tidak hanya bagi mereka yang telah memiliki usaha).

Untuk mendapatkan pembiayaan BTPN Syariah memiliki tahapan mekanisme yang harus dijalankan. Tahap Pertama, ialah Pre Marketing yang merupakan tahapan perkenalan kepada tokoh-tokoh 
formal/informal untuk menjelaskan maksud dan tujuan serta skema pembiayaan yang akan dilakukan kepada nasabah. Tahap Kedua adalah Mini Meeting, yaitu pertemuan dengan nasabah dan memperkenalkan diri dan produk, menggali potensi dan kebutuhan ibu-ibu calon nasabah dengan membangun suasana akrab untuk mencari sumber motivasi untuk mewujudkan mimpi. Tahap Ketiga, Projection Meeting adalah pertemuan formal dengan rata-rata 15 calon nasabah untuk menggali mimpi di rumah salah satu calon nasabah, dan menjelaskan secara lengkap tujuan dan aturan Paket Masa Depan. Tahap Keempat adalah Survei dan Wawancara yang ditujukan untuk menggali lebih mendalam informasi dan karakter ibu-ibu yang akanmenjadi calon nasabah kita. Setelah survei, para calon nasabah mengkuti Pelatihan Dasar Keanggotaan (PDK) yang menjelaskan tentang paket masa depan dan bagaimana manajemen pengelolaan keuangan usaha. Tahap terakhir adalah tahap pencairan pembiayaan, dimana nasabah mendapatkan sesuai dengan pengajuan yang di inginkan oleh nasabah.

BTPN Syariah Sepanjang 2014 mampu menjaga rasio pembiayaan bermasalah (Non Performing Financing/NPF) hanya sebesar 1,3\%. Kualitas Pembiayaan Murabahah yang disalurkan di segmen Tunas Usaha Rakyat mengkontribusi rasio NPF sebesar 0,9\%, sedangkan kualitas pinjaman atas Legacy Portfolio mengkontribusi rasio NPF sebesar 22,4\%.

Pembiayaan mikro yang dilakukan oleh BSM dan BTPN Syariah merupakan bukti konkrit perbankan syariah dalam mempercepat pengimplementasian inklusi keuangan di Indonesia. Produk-produk perbankan syariah yang memang sudah pro poor akan membantu percepatan implementasi inklusi keuangan Indonesia.

Tingkat inklusi keuangan perbankan syariah Indonesia bisa dilihat dari analisis Indeks Keuangan Inklusif (IKI). Pada penelitian ini penulis mengukur Indeks Keuangan Inklusif (IKI) pebankan syariah dengan menggunakan indikator Bank Indonesia untuk mengukur tingkat financial inclusion, yaitu dengan menggunakan dimensi akses (access), penggunaan (usage) dan kualitas (quality) dari layanan perbankan syariah. Pengukuran ini dilakukan tehadap dua bank umum syariah yaitu BSM dan BTPN syariah.

1. Dimensi Akses (access)

Dimensi Akses digunakan untuk mengukur kemampuan penggunaan jasa keuangan formal, sehingga dapat dilihat terjadinya potensi hambatan untuk membuka dan mempergunakan rekening bank, 
seperti biaya atau keterjangkauan fisik layanan jasa keuangan (kantor bank, ATM, dll.).

\begin{tabular}{|l|c|l|l|c|l|l|}
\hline \multicolumn{7}{|c|}{ DIMENSI AKSES (ACCESS) } \\
\hline $\begin{array}{c}\text { Nama } \\
\text { bank }\end{array}$ & $\begin{array}{c}\text { Jumlah kantor per } \\
\text { 1000 penduduk } \\
\text { dewasa }\end{array}$ & \multicolumn{2}{c|}{$\begin{array}{c}\text { Jumlah ATM per 1000 } \\
\text { penduduk dewasa }\end{array}$} \\
\hline & 2014 & 2015 & 2016 & 2014 & 2015 & 2016 \\
\hline BSM & 0,865 & 0,865 & 0,864 & 164,737 & 169,399 & 367,225 \\
\hline $\begin{array}{l}\text { BTPN } \\
\text { syariah }\end{array}$ & 0,030 & 0,030 & 0,030 & - & - & - \\
\hline
\end{tabular}

Pada dimensi akses terlihat bahwa jumlah kantor BSM setiap 1000 penduduk dewasa memang masih sedikit. Tahun 2014 saja setiap 1000 penduduk dewasa Cuma tersedia 0,865 kantor, tahun 2015 juga sama dan tahun 2016 ada pengurangan satu kantor BSM. Layanan kantor cabang yang sedikit ini diperkuat dengan jumlah ATM yang cukup banyak. Tahun 2014, setiap 1000 penduduk dewasa terdapa 164,737 jumlah ATM, tahun 2015 jumlah tesebut naik menjadi 169,399, dan tahun 2016 ini BSM mengalami peningkatan jumlah ATM yang signifikan, yaitu setiap 1000 penduduk dewasa tersedia 367,225 jumlah ATM. Hal ini mengindikasikan bahwa BSM terus melakukan peningkatan jaringan kantor maupun ATM untuk meningkatkan akses masyarakat terhadap lembaga keuangan.

BTPN syariah sebagai bank umum syariah ke 12 yang baru efektif beroperasi tahun 2014 memang masih sangat kurang jumlah kantor cabangnya. Hanya ada 30 kantor cabang se Indonesia. Kekurangan analisis dimensi akses ini adalah karena penulis tidak mendapatkan angka rill jumlah ATM BTPN syariah.

Di dalam annual report tahun 2014 BTPN syariah dijelaskan bahwa Pengembangan jaringan kantor baik berupa Kantor Cabang maupun Kantor Fungsional Operasional di tahun 2015 akan dijadikan salah satu faktor yang penting di tahun 2015 sehingga pelayanan tim Mobile Marketing Syariah (MMS) yang saat ini melayani segmen nasabah Tunas Usaha Rakyat bisa lebih diperluas. BTPN Syariah turut serta mendukung program OJK dalam agenda Financial Inclusion dengan menjadi bank penyelenggara Layanan Keuangan Tanpa Kantor dalam rangka Keuangan Inklusif atau yang lebih dikenal dengan nama LAKU PANDAI. Pengembangan produk, layanan maupun 
infrastruktur pendukung akan dikembangkan oleh BTPN Syariah secara mandiri ataupun bekerjasama dengan Bank BTPN. Untuk penguatan struktur permodalan Bank, maka pemegang saham akan menambahkan modal sehingga di tahun 2015 BTPN Syariah diharapkan menjadi Bank dengan kategori BUKU 2 yaitu Bank dengan modal diatas Rp1 triliun. Penguatan modal ini diharapkan mampu meningkatkan produk dan layanan yang semakin beragam serta penguatan infrastruktur penunjang baik teknologi informasi maupun operasional. Pada segmen Tunas Usaha Rakyat, BTPN Syariah akan terus menerus mengembangan bisnis sejalan dengan perkembangan nasabah. Pengembangan produk juga akan dikembangkan baik produk Paket Masa Depan Lanjutan maupun pengembangan produkproduk mikro untuk komunitaskomunitas baru. Dalam memperkuat infrastruktur untuk menunjang sektor pendanaan bank, maka Layanan Anjungan Tunai mandiri (ATM) juga akan diluncurkan di tahun 2015. Selain itu beberapa produk tabungan seperti tabungan berencana akan dikembangkan sehingga komposisi dana pihak ketiga diharapkan akan menjadi lebih baik. Selain memperkuat infrastruktur penunjang, BTPN Syariah juga akan memperkuat Program Daya sebagai bagian dari pemberdayaan kepada nasabah. Program Daya BTPN Syariah akan terus dikembangkan dan ditingkatkan melalui ketiga pilar inisiatifnya yaitu Daya Sehat Sejahtera, Daya Tumbuh Usaha dan Daya Tumbuh Komunitas dengan bekerjasama dengan BTPN. Pengadaan rumah murah dan terjangkau juga menjadi program andalan penting yang akan diujicobakan tahun ini agar kelompok pra/cukup sejahtera dapat memiliki rumah impian. (Annual Report BTPN syariah, 2014).

Pada annual report tersebut terlihat bahwa BTPN syariah konsen pada implementasi inklusi keuangan melalui pemberdayaan kelompok miskin perempuan. Untuk menjangkau para kelompok miskin perempuan ini sudah pasti BTPN syariah melakukan berbagai inovasi dalam rangka mempermudah akses masyarakat terhadap BTPN syariah.

2. Dimensi Penggunaan (usage)

Dimensi Penggunaan adalah dimensi yang digunakan untuk mengukur kemampuan penggunaan aktual produk dan jasa keuangan, antara lain terkait keteraturan, frekuensi dan lama penggunaan. Pada akhir tahun 2014 saja BSM tercatat sudah melayani nasabah pendanaan dan pembiayaan sebesar 5.569 .887 orang dan tahun 2015 sebesar 9.633.27 orang. BTPN syariah pada desember 2014 sudah Melayani lebih dari 1,5 juta nasabah. BTPN Syariah meskipun baru ada sejak 
2014, namun secara perlahan memberikan sumbangsih nyata bagi jutaan rakyat Indonesia. Keuangan inklusif menggunakan dimensi akses bisa terlihat pada table dibawah ini.

\begin{tabular}{|l|c|c|c|c|}
\hline \multicolumn{3}{|c|}{ DIMENSI PENGGUNAAN (USAGE) } \\
\hline Nama bank & \multicolumn{2}{|c|}{$\begin{array}{c}\text { Jumlah DPK per } \\
\text { 1000 penduduk } \\
\text { dewasa } \\
\text { (dalam miliar rupiah) }\end{array}$} & $\begin{array}{c}\text { Jumlah pembiayaan } \\
\text { per 1000 penduduk } \\
\text { dewasa } \\
\text { (dalam miliar rupiah) }\end{array}$ \\
\hline BSM & $\mathbf{2 0 1 4}$ & $\mathbf{2 0 1 5}$ & $\mathbf{2 0 1 4}$ & $\mathbf{2 0 1 5}$ \\
\hline BTPN syariah & 59,821 & 62,11 & 49,133 & 51,09 \\
\hline
\end{tabular}

Pada dimensi akses telihat bahwa jumlah pembiayaan yang diberikan oleh BSM maupun BTPN syariah memang masih sangat kecil, tetapi positifnya adalah perbankan syariah selalu menunjukkan pertumbuhan setiap tahunnya. Pertumbuhan yang signifikan itu pastinya diikuti oleh peningkatan akses masyarakat akan perbankan syariah melalui pendanaan dan pembiayaan.

3. Dimensi Kualitas (quality)

Dimensi Kualitas adalah dimensi yang digunakan untuk mengetahui apakah ketersediaan atribut produk dan jasa keuangan telah memenuhi kebutuhan pelanggan. Pengukuran terhadap dimensi ini masih sukar untuk dilakukan dan saat ini beberapa lembaga internasional yang concern dalam pengembangan financial inclusion sedang menyusun indikator dari dimensi kualitas beserta tools yang dipergunakan. Secara umum The Alliance for Financial Inclusion (AFI) telah menyepakati prinsip-prinsip yang dipergunakan dalam menyusun indikator dari dimensi kualitas, meliputi ringkas (conciseness), spesifik (specifity), sederhana (simplicity), adanya perbaikan (improvement), dan client perspective.

Penulis memang tidak melakukan pengukuran terhadap dimensi kualitas ini karena pengukurun memang sukar dilakukan apalagi bagi perbankan syariah yang dinilai masih baru. Meskipun demikian, perbankan syariah sebenarnya sudah memperlihatkan kualitasnya dalam implementasi inklusi keuangan. Perbankan syariah selalu menambah layanan kantor dan meningkatkan kualitas produk dalam rangka percepatan implementasi inklusi keuangan. 
Meskipun perbankan syariah masih terbilang kecil di Indonesia, tapi komitmen perbankan syariah dalam mengembangkan inklusi keuangan di Indonesia sangat tinggi. Komitmen ini didukung oleh pertumbuhan perbankan syari'ah yang signifikan setiap tahun. Dua hal ini menjadi kekuatan perbankan syariah dalam rangka memberikan akses keuangan bagi unbankable people sampai pada masyarakat grass root sekalipun.

\section{Kesimpulan}

Sejak berdirinya Bank Muamalat tahun 1992 sampai sekarang bank syariah terus mengalami pertumbuhan yang signifikan. Data Statistik Perbankan Syariah OJK per Maret 2016 menjelaskan bahwa sampai saat ini di Indonesia sudah ada 12 Bank Umum Syariah dengan 2138 jumlah kantor, 22 Unit Usaha Syariah dengan 693 kantor cabang, 1.399 kantor cabang pembantudan, dan 427 kantor kas serta 162 Bank Pembiayaan Rakyat Syariah (BPRS) dengan 471 kantor cabang.

Penyebab ekslusi keuangan pada perbankan syariah terdidentifikasi pada sisi permintaan (nasabah) dan sisi penawaran (bank). Ekslusi keuangan dari sisi permintaan disebabkan karena: a) Kurangnya pengetahuan tentang perbankan syariah, b) Rendahnya pendapatan, dan c) Tidak adanya jaminan. Ekslusi keuangan dari sisi penawaran disebabkan oleh: a) Jarak kantor yang jauh dari tempat tinggal, b) Prosedur yang rumit, c) Ketidaksesuaian produk dengan kebutuhan, d) Bahasa yang tidak efektif, e) Perilaku pegawai, f) Waktu operasional bank, dan g) Technological innovation.

Indeks Keuangan inklusif perbankan syariah Indonesia selalu menalami peningkatan setiap tahun. Hal ini membuktikan bahwa impelementasi financial inclusion melalui perbankan syariah selalu mengalami peningkatan. BSM dan BTPN syariah merupakan dua bank umum syariah yang sangat konsen dalam pengimplementasian inklusi keuangan. BSM melalui warung mikronya selalu berusaha memberikan akses pembiayaan bagi unbankable people. BTPN syariah bahkan memiliki visi khusus dalam impelementasi inklusi keuangan dan meiliki produk pembiayaan khusus memperkuat inklusi keuangan, yaitu Paket Masa Depan (PMD). Paket Masa Depan (PMD) adalah program terpadu BTPN Syariah yang diberikan kepada sekelompok wanita di pedesaan yang ingin berusaha dan memiliki impian untuk merubah hidup, tetapi tidak memiliki akses ke layanan perbankan. 
Meskipun perbankan syariah masih terbilang kecil di Indonesia, tapi komitmen perbankan syariah dalam mengembangkan inklusi keuangan di Indonesia sangat tinggi. Komitmen ini didukung oleh pertumbuhan perbankan syari'ah yang signifikan setiap tahun. Dua hal ini menjadi keuatan perbankan syariah dalam rangka memberikan akses keuangan bagi aunbankable people sampai pada masyarakat grass root sekalipun.

\section{Daftar Pustaka}

Ahmad dan Malik. "Financial Sektor Development and Economic Growth: An Empirical Analysis of Developing Contries," Journal of economic cooperation and development, 30, 1 (2009): 17-40.

Bank Indonesia, Kebijakan Keuangan Inklusif: Implementasi Kebijakan dan Program Kerja pada satker-satker Terkait, Oktober 2011.

C Bold," Branchless Banking in Pakistan: A Laboratory for Innovation," Washington, DC World Bank, World Bank, 2011 https://openknowledge.worldbank.org/handle/10986/9449

License: CC BY 3.0 Unported

Cheng, Xiaoqiang dan Hans Degryse. "The Impact of Bank and NonBank Financial Institutions on Local Economic Growth in China." Journal of Financial Sevices Research Volume 37, Issue 2-3, (2010): 179-199.

Davlin, James F. "A Detailed Study of Financial Exclusion in the UK." Journal of Consumer Policy, Vol. 28, Issue 1 (2005): 75-108.

Dasgupta, Rajaram. "Two Approaches to Financial Inclusion." Economic and Political Weekly, Vol. 44, No. 26/27, (Juni 2009): 41-44.

Dev, S. Mahendra. "Financial Inclusion: Issues and Challenges." Economic and Political Weekly, Vol. 41, No. 4,1 (Oktober 2006): 4310-4313.

Kamath, Rajalaxmi. "Financial Inclusion Vis-À-Vis Social Banking." Economic and Political Weekly, Vol. 42, No. 15 (Apr. 14-20, 2007): 1334-1335.

K. C. Chakrobarty. "Financial Inclusion and Banks: Issues and Perspective." RBI Monthly Bulletin (November 2011) http://rbidocs.rbi.org.in/rdocs/Bulletin/PDFs/02SEPC1111FL.p df (Diakses tanggal 16 Mei 2014 jam 14.05 WIB). 
Kunt, Demirguc, et.al. "Islamic finance and financial inclusion: measuring use of and demand for formal financial services among Muslim adults." The World Bank: Development Research Group Finance and Private Sector Development Team (October 2013)

Lee, Jhong-Wha. "Economic growth in Asia: Determinants and prospects." Science Direct, Volume 24, Issue 2, (Maret 2012): $101-113$.

Leyshon, Andrew dan Nigel Thrift. "Geographies of Financial Exclusion: Financial Abandonment in Britain and the United States." The Royal Geographical Society with The Institute of British Geographers, Vol. 20, No. 3 (1995) http://www.jstor.org/stable/pdf/622654.pdf?acceptTC=true (Diakses tanggal 9 Mei 2015 Jam 08.50 WIB).

Reyes, Giovanna Priale. "Financial Inclusion Indicators for Developing Countries: The peruvian case," Intendencia Malaysis (2010). http://www.afiglobal.org/sites/default/files/fidwg_peruindicators_priale.pdf (Diakses tanggal 10 Mei 2015 jam 13.05 WIB).

Rahyani, Wiwin Sri. "Independensi Otoritas Jasa Keuangan dalam Perspektif Undang-Undang Nomor 21 Tahun 2011 tentang Otoritas Jasa Keuangan." Indonesia Journal of Legislation Vol. 9 No. 3. (Oktober 2012).

Rini, Deasy Puspita. "Review Kajian Mingguan LiSEnSi Financial Inclusion." Lisensi UIN Jakarta (25 Desember 2013) https://lisensiuinjkt.wordpress.com/2013/12/25/review-kajianmingguan-lisensi-financial-inclusion// (Diakses 23 Mei 2015 jam 12.55 WIB).

Steelyana, Evi. "Perempuan dan Perbankan: Sebuah Tinjauan Tentang Peran Inklusi Keuangan Terhadap Pengusaha Umkm Perempuan Di Indonesia.” Journal The Winners, Vol. 14 No. 2, (September 2013): 95-103.

. "The Role of Financial Inclusion in the implementation of Financial Reporting Standards For SMEs (Small Medium Enterprise) in Indonesia in facing the ASEAN Economic Community in 2015." Social Science Research Network November 15, 2014. Diakses melalui http://ssrn.com/abstract=2525010 tanggal 24 Agustus 2015. 
Ahmad Rodoni, Novia Nengsih, Lili Supriyadi 